Hauser had his share of critics even before the investigation began. In 1995, a paper from Hauser's group in the Proceedings of the National Academy of Sciences ${ }^{5}$ caught the eye of evolutionary psychologist Gordon Gallup of the State University of New York at Albany. The paper asserted that tamarins can recognize their reflection in a mirror rather than assuming that the reflection is another monkey. Gallup was intrigued - his earlier work ${ }^{6}$ had indicated that although chimpanzees could recognize themselves in a mirror, monkeys could not. He asked to see video footage of the experiment.

But when Gallup reviewed the tapes, he says he found no evidence of self-recognition. He published his concerns ${ }^{7}$ in Animal Behaviour in 1997. Hauser published a rebuttal in the same issue ${ }^{8}$, but four years later, in a paper in the American Journal of Primatology $y^{9}$, reported that he had been unable to reproduce the results of the earlier paper.

That does not necessarily mean the original claim was wrong, says Mark Liberman, a linguist at the University of Pennsylvania. Subtle variations between experiments can lead to contradictory results without clearly indicating that one result is wrong. But Gallup thinks that the paper should have been withdrawn or corrected, especially given his experience with the raw data. "Unfortunately, I think most people are unaware of the published failure to replicate," he says, noting that the original 1995 paper has been cited 40 times, whereas the 2001 paper has been cited only 10 times.

De Waal worries that the field will face more problems as pressure builds for young professors to publish in high-profile journals. "Now scientists facing tenure are asked to produce something new and exciting that can be summed up in three pages," he says. "It's craziness, because actually the study of animal behaviour is painstaking, slow, laborious, and rarely leads to unambiguous results."

\section{Heidi Ledford}

1. Hauser, M. D. et al. Cognition 86, B15-B22 (2002).

2. Hauser, M. D., Glynn, D. \& Wood, J. Proc. R. Soc. B 274, 1913-1918 (2007)

3. Hauser, M. D. \& Wood, J. N. Proc. R. Soc. B doi:10.1098/ rspb.2010.1441 (2010)

4. Wood, J. N. et al. Science 317, 1402-1405 (2007)

5. Hauser, M. D. et al. Proc. Natl Acad. Sci. USA 92, 10811-10814 (1995)

6. Gallup, G. G. Science 167, 86-87 (1970)

7. Anderson, J. R. \& Gallup, G. G. Anim. Behav. 54, 1563-1567 (1997)

8. Hauser, M. D. \& Kralik, J. Anim. Behav. 54, 1568-1571 (1997).

9. Hauser, M. D. et al. Am. J. Primatol. 53, 131-137 (2001).

\title{
FDA challenges stem-cell clinic
}

How should clinics that treat patients with injections of their own stem cells be regulated? That question is about to test the jurisdiction of the US Food and Drug Administration (FDA) in a landmark legal battle - and is fuelling a war of words between doctors marketing such therapies and academics who urge caution.

The FDA asserted its authority on 6 August, when it requested a federal injunction from the US District Court of the District of Columbia to prevent stem-cell clinic Regenerative Sciences in Broomfield, Colorado, from preparing its treatments. The company isolates, cultures and processes adult stem cells from a patient's bone marrow or synovial fluid. Doctors then inject the cells to treat fractures, torn tendons and other ailments. The clinic charges patients US\$7,0009,000 , carries out about 20 procedures each month, and says it will fight the FDA's injunction. Unlike conventional bone-marrow transplants of blood-forming stem cells, Regenerative Sciences' procedure relies on mesenchymal stem cells that can potentially transform into bone, cartilage or fat.

In July 2008, the FDA told Regenerative Sciences that its treatments are drugs according to the Federal Food, Drug and Cosmetic Act, and biological products under the Public Health Service Act. But the company did not apply for FDA approval and continued to offer the treatment. Now the agency says that the company is not following good manufacturing practice, and that the treatment's safety and efficacy is unproven.

But Christopher Centeno, Regenerative Sciences' medical director, argues that as the treatment uses a patient's own stem cells, it is a medical procedure akin to in vitro fertilization, and therefore none of the FDA's business. He adds that his treatment has a much better safety record than conventional surgery (C. J. Centeno et al. Curr. Stem Cell Res. Ther. 5, 81-93; 2010) and that animal (see go.nature.com/PiFFyf) and imaging (C. J. Centeno et al. Pain Physician 11, 343$353 ; 2008)$ studies have proved it effective.

The FDA's demand for scientific evidence from clinical trials "is a valid position. But it is not the only position," Centeno told Nature. He says that it is sufficient to follow the guidelines of the International Cellular
Medicine Society (ICMS), based in Salem, Oregon, an association of 1,100 physicians and patients that he co-founded and of which he is medical director.

Centeno and his supporters say that the FDA's request for an injunction is another blow for stem-cell clinics in their Davidand-Goliath struggle with an industry-led alliance that wants to put a stranglehold on stem-cell therapies and restrict individuals' use of their own cells. In an open letter on 30 July, ICMS executive director David Audley accused the International Society for Stem Cell Research (ISSCR), based in Deerfield, Illinois, and including some 3,500 stem-cell researchers, of setting out to close their clinics. Motivated by the interests of a pharmaceutical industry unlikely to profit from the treatments, Audley says, the society wants to "change the laws in all civilized countries to outlaw these therapies". When questioned by Nature, however, Audley admitted he had no hard evidence for these assertions.

ISSCR president Elaine Fuchs of the Rockefeller University in New York denies the claims. Although the society gets $12 \%$ of its funding from industry, its aim is to "motivate basic science" and not to support industrial interests, she says.

But the ISSCR is worried about unproven stem-cell treatments. In June, it established a service that, on request, will judge whether a treatment or clinic is safe and effective (see Nature 466, 7-8; 2010). Douglas Sipp of the RIKEN Centre for Developmental Biology in Kobe, Japan, and a member of the ISSCR's Task Force on Unproven Stem Cell Treatments, says that "the consequences could be severe" if Regenerative Sciences wins the US District Court case, likely to begin next summer. "Companies would likely feel empowered to ignore requirements for demonstrable safety and efficacy of autologous medicinal products, creating an 'anything goes' atmosphere," he says. "It would be, as they say, a bad thing."

But Centeno senses a landmark victory. "If we win, the entire regulatory structure for autologous cell processing, with or without culture, will be rewritten such that any physician using good practices and treating patients responsibly can use stem cells as part of his or her medical practice," he says. David Cyranoski 